\title{
"Midway in our Life's Journey, I went Astray from the Straight Road and Woke to Find Myself...": Where has a Literary Translator Found Himself? (Translation Sketch)
}

Irina S. Alekseeva*

Herzen State Pedagogical University of Russia St. Petersburg School of Conference Interpreting and Translation 3 a Kazanskaya Str., Saint-Petersburg, 191186, Russia

Received 20.01.2015, received in revised form 24.02.2016, accepted 05.03.2016

The article deals with the problem of changes in the appearance and functions of literary translation, as a respond to the contemporary perception and interpretation of fiction works composing the World Culture. The format of translation sketch allows the author to reason in a free from about how translators become creators of meta-linguistic markers in the target culture, concepts and traditions, i.e. those elements, which are crucially important for any culture. The material and remarkable examples used in the work provide the author with an opportunity to remind the readers that skills and experience of literary translators make a vital contribution to enrich the content of the Russian culture.

Keywords: literary translation, fiction work, literary culture, bridges, meta-language, aphorism, allusion.

DOI: 10.17516/1997-1370-2016-9-3-687-694.

Research area: philology.

Under the Year of Literature in Russia it's time for literary translation, almost forgotten within the last quarter-century, to be brought back. For quite a long time the discussion has mainly been focused on marketing types of translation, e.g. simultaneous interpreting, while literary translation has been kept in the background. Along this way, there has been another consideration about its new nomination"standardized translation" - resulted in differentiation of two notions the first of which is considered as a translation (interpreting) that involves bookish way of speaking, whilst literary translation means the translation of fiction works.

It is now a common knowledge that literary works have already passed their Golden Age (the $19^{\text {th }}$ century) through. It even has been Magister Vita - not the least fact explaining its widespread use as a propaganda tool in the $20^{\text {th }}$ century.

(C) Siberian Federal University. All rights reserved

* Corresponding author E-mail address: i.s.alexeeva@gmail.com 
In the present time, fiction is a type of art, and, as it seems, has left the social van. A play with words has become sophisticated, complex and ambiguous... Since so, literary translation has to explore new horizons by transferring the whole delicacy of postmodernism.

Still, as a rule, the culture breathes by two things, i.e. traditions and bridges. The last named are committed to translators.

However, the image of literary translation has changed, and, consequently, its function has transformed in the same way. I mean, not only a written word has now fallen to everyone's share all of us write texts - but also translation has followed the same suit - people do translate: in the Internet one can find translations of almost all books. Along this way, a complex and extensive representation of the source text is built.

In this context, fragments and certain words from the translated fiction text serve as metasigns, markers of the culture, and by performing in this function, change importance of the source text. Thus, within the host culture translators turn into creators of the specific meta-language of the culture: it is not the author who speaks with us, but translators.

Now, I'd like to touch on this phenomenon, analyze some aspects of the language's life and authorship of its components. It won't be a question of readers, but speakers of the mothertongue concerned as a basis for the culture. In this sense, we come across a number of different cases.

Case 1: People associate aphoristic expressions with a certain author or sometimes even with a translator (as a rule, with the most well-known one), - and they are sadly at fault! Let's first turn to Dante Alighieri and, then - to Shakespeare!

1) «Земную жизнь пройдя до половины,

Я очутился в сумрачном лесу,

Утратив правый путь во тьме долины.
Каков он был, о, как произнесу,

Тот дикий лес...»

("Divine Comedy" by Dante Alighieri, Inferno (Hell), Song 1; translated by Mikhail Lozinsky).

2) а) «Оставь надежду, всяк сюда входящий...» (poetry translation by Dmitry Min, one of the first translators of "Divine Comedy"; the phrase has been edited into: «Оставь надежду всякъ, сюда идущій!» The whole sign at the jaws of the Hell says "Abandon all hope, ye who enter here" (rus.: «Входящие, оставьте упованья»; translated by Mikhail Lozinsky); b) the Italian variant of the same phrase - "Lasciate ogni speranza voi ch 'entrate” - literary means "Оставьте всякую надежду, вы, входящие сюда» (е.g. «Над их бровями надпись ада: Оставь надеждунавсегда» in "Eugene Onegin" by A.S. Pushkin, Ch. 3, Verse 22).

Speaking about the Russian translation of Shakespeare's works, we are likely to mention three names: Mikhail L. Lozinsky, Boris L. Pasternak and Tatiana L. Schepkina-Kupernik. Still, as it turns out, the most aphoristic and fancied by readers Shakespeare's phrases are translated by quite other translators

3) «Быть или не быть - вот в чем вопрос...» ("Hamlet" by W. Shakespeare (15641616), translated by N. Gnedich and K.R. = Konstantin Romanov); or: «Быть иль не быть, вот в чем вопрос. / Достойно ль / Терпеть без ропота позор судьбы / Иль надо оказать сопротивленье?» (“Hamlet” by W. Shakespeare, Act 3, Scene 1; translated by Nikolai A. Polevoy (1796-1846) in 1837). Later on, these verses were repeated in the translation by Boris Pasternak.

4) «Есть многое на свете, друг Горацио, / Что и не снилось нашим мудрецам» ("Hamlet" by W. Shakespeare, Act 1, Scene 4; translated by Mikhail P. Vronchenko in 1828).

5)«Офелия! Онимфа!Помянименявсвоих молитвах...» (“Hamlet” by W. Shakespeare, 
Act 3, Scene 3, Hamlet's Monologue). This phrase aroused as the result of two translations by outstanding Russian writers and translators Nikolai A. Polevoi (rus.: «Офелия! О нимфа! помяни грехи мои в молитвах») and Nikolai Kh. Ketcher (rus.: «O нимфа, помяни меня в своих молитвах»).

6) «Нет повести печальнее на свете, чем повесть о Ромео и Джульетте» (“Romeo and Juliet" by W. Shakespeare; similarly translated by I. P. Grekov (1810-1866) and Apollon Grogoriev (1822-1864)).

7) «Башмаков еще не износила» (“Hamlet” by W. Shakespeare, Act 1, Scene 2, Hamlet's Monologue; translated in 1837 by Nikolai A. Polevoi (1796-1846), a writer, critic and publicist: «О, женщины, ничтожество вам имя! / Как? месяц... Башмаков еще не износила, / В которых шла за гробом мужа»).

8) «Она меня за муки полюбила, / А я ее за состраданье к ним» (“The Tragedy of Othello, The Moor of Venice" by W. Shakespeare, Act 1, Scene 3; translated by Pyotr I. Veinberg (1831 1908)).

9)«Неладно что-товдатскомкоролевстве» (eng.: "Something is rotten in the state of Denmark" in "Hamlet" by W. Shakespeare, Act 1, Scene 4; Marcellus's lines when he sees the Ghost of Hamlet's Father meeting Hamlet; translated by A. Kroneberg).

10) «Распалась связь времен» ("Hamlet" by W. Shakespeare; translated by A. Kroneberg in 1844). In the final monologue (Act 1) Hamlet cries, swearing to revenge the death of his father: "The time is out of joint: $\mathrm{O}$ cursed spite/ That ever I was born to set it right! (rus.: «Распалась связь времен./ Зачем же я связать ее рожден!»

11) «Чума на оба ваших дома!» (“'Romeo and Juliet", 1597, by W. Shakespeare, Act 3, Scene 1; translated by Tatiana L. SchepkinaKupernik (1874-1952)). Mercutio, being a friend of Romeo Montague, stands up for his honour and dies at the House of Capulet member's hands. He fells a victim of the conflict between two family Houses (Montague and Capulet), whereof he bitterly regrets, feeling the death coming: "A plague o'both your houses! / They have made worms' meat me: / I have it, and soundly too... Your houses!” (rus.: «Чума, чума на оба ваших дома! / Я из-за них пойду червям на пищу, / Пропал, погиб. Чума на оба ваших дома!»).

12) «Коня! Коня! Полцарства за коня!» (eng.: "A horse, a horse! My kingdom for a horse!" in "Richard III" by W. Shakespeare, Act 5, Scene 4; translated by Yakov G. Brianskii (1790-1853)). The translation was made by Yakov Brianslii not from the original source text, but form it's French prose variant, that is why it cannot be called a close translation. Presumably, the translator's work was influenced by the Russian fairy-tale tradition, when a tzar promises a "honest young man" to marry daughter off and "half of the kingdom" for his bravery. The phrase has become popular due to Pavel Mochalov (1800-1848) and his outstanding actor play as Richard III. This fact was mentioned once again in "Arts and Truth" (rus.: «Искусство и правда») by Apollon Grigoriev in 1854: «И помню, как в испуге диком / Он леденил всего меня / Отчаянья последним криком: / «Коня, полцарства за коня!»

Case 2: A popular phrase is related to the author, while it has no author at all. Let's first give an example from false "Shakespeare":

13) «Мавр сделал свое дело, мавр может уходить...» Originally, this phrase is found in the play "Fiesco's Conspiracy at Genoa" (Act 3, Scene 4) by Friedrich Schiller (1759 - 1805). The phrase is spoken by the Moor, finding himself as a squeezed orange after he helped Fiesco to arrange the Republican revolt against the tyrant Doria, Doge of Genoa. The line has become a saying which describes a cynical attitude towards a man of no longer necessity. 
Despite the fact that this translation was made by Nikolai I. Gnedich in 1804, there were other variants, for example «...Мавр может уйти...» in the work by Gerbel.

Then let's turn to false "Johann Goethe": particularly, to the phrase which is commonly but mistakably taken form "Faust":

14) «Остановись, мгновенье, ты прекрасно...». This line can easily be found in a poem of the $19^{\text {th }}$ century: by entering in the search-field of Google остановись мгновенье ты прекрасно яхонтов, we finally get the poem "Genio Loci" (1849) by Yakhontov with the following ending: «Не испытуй грядущего напрасно, / Мимолетящим благом дорожи / И, на лету схватив его, скажи: «Остановись, мгновенье, ты прекрасно!». Alexander Yakhontov was a Lyceum student and his poem was dedicated to the Lyceum, particularly, to the famous monument - a former bust of Alexander I decorated with the sign "Genio Loci”. The bust soon disappeared, leaving its socle with the text standing all alone. This is undoubtedly allusion to "Faust", but not a citation. (Cf.: "When thus I hail the Moment flying: / "Ah, still delay - thou art so fair!” - rus.: «Мгновенье! О как прекрасно ты, повремени!» translated by Boris Pasternak; «... мгновенье! Прекрасно ты, продлись, постой!» translated by N. Kholodovsky).

Case 3: Some successfully translated titles of fiction works becomes proverbial phrases. Still, despite the fact, that the title is mainly a fruit of hard work and pains of translators, as a rule, their names are not seen behind the title.

15) «Принцесса на горошине» (the title of a Danish fairy-tale by H.C. Andersen (1805-1875), telling about a princess being so sensitive, that she feels a small pea lying under 12 mattresses and 12 duvets. Who did create this title? It was Anna and Pyotr Ganzen, a Russian married couple, who introduced H.C. Andersen and this work in particular to the reader.
16) «Гадкий утенок» (“The Ugly Duckling” by H.C. Andersen; translated by Anna and Pyotr Ganzen).

Presumably, one of criteria for a successful translation of the title can be such cases when it looses the link with the source work and becomes a wide metaphoric formula, as it has been shown in examples 15 and 16.

17) «Над пропастью во ржи» (eng.: “Тhe Catcher in the Rye" a novel by an American writer J.D. Salinger, 1951; translated by Rita Rait-Kovaleva). Other variants of translation into Russian include «Обрыв на краю ржаного поля детства», «Ловец на хлебном поле». Examples of metaphorical use of the title:

a) «Вот еще одни потерялись... над пропастью во ржи...жаль».

b) «Сижу над пропастью во ржи - внизу купаются моржи».

18) «Гроздья гнева» (eng.: “Grapes of Wrath", an America novel by John Steinbeck (1902-1968), 1940; translated by Natalia Volzhina). Examples of use:

a) «ГроздьяГнева.Рейтингмежэтнической напряженности в регионах России».

19) «Зима тревоги нашей» (eng.: “The Winter of Our Discontent" an American novel by John Steinbeck, 1961; translated by N. Volzhina and E. Kalashnikova). The novel tells us about how a desire for material wealth, which fights all other human feelings, leads to irreversible destruction of a person. The title has become a well-known paper cliché frequently found in the Russian print media with a suitable substitution of the word "winter" for others, contextually appropriate variants:

a) «Весна тревоги нашей. Российский кинорежиссер Александр Сокуров рассказал о конфликте внутри российского общества».

b) «Весна тревоги нашей. Сухие цифры не подтверждают тезис о том, что острая фаза кризиса пройдена». 
c) «Дороги и тепло: зима заботы нашей».

d) «Зима заботы нашей. На всю зиму запаслись в Первомайском районе топливом «черным золотом» из Кузбасса».

20) «Игра в бисер» (germ.: "Das Glasperlenspiel", 1934, eng.: "The Glass Bead Game", a German novel by Herman Hesse; translated by S. Apt). In the general introduction the author says: "The Glass Bead Game is [...] a mode of playing with the total contents and values of our culture". Examples:

a) «Колдовская игра в этот бисер сверкающих слов!..»

b) «Игра в бисер с Игорем Волгиным» (а TV program on channel Russia-K)

21) «Каждый умирает в одиночку» (germ.: "Jeder stirbt für sich allein"; eng.: "Every Man Dies Alone", a novel by German author Hans Fallada (Rudolf Ditzen; 1893-1947), 1947; translated in 1948):

a) «Каждый умирает в одиночку! - К сожаленью это слишком точно. Ничего уже не выбирает. Просто умирает, умирает...» (by Р. Davydov; available at http://www.inpearls.ru/).

b) «Каждый умирает в одиночку? Европа не может справиться с долгами Афин» (available at http://www.newtimes.ru/articles/ detail/17595/\#hcq=Byi4UCp).

22) «Кошка, которая гуляла сама по себе» ("The Cat That Walked by Himself", 1902, an English fairy-tale by Joseph Rudyard Kipling (1865-1936), in "Just So Stories for Little Children"; translated by N. Loktionova). The work is widely known mainly due to translations by Korney Chukovslky and Samuil Marshak (rus.: «Кошка, гулявшая сама по себе»):

а) «Татьяна Васильева - кошка, которая гуляет сама по себе.»

b) «Тест-драйв Jaguar XF: кошка, которая гуляет сама по себе» (available at: http:// www.mhealth.ru/technics/garage/test-drajv- jaguar-xf-koshka-kotoraya-gulyaet-sama-posebe/\#ixzz40MDtWDLN

23) «Жизнь взаймы» (germ.: “Geborgtes Leben", 1959, eng.: "Heaven Has No Favourites", a novel by Erich Maria Remarque (1898-1970); translated into Russian by L.B. Chyornaya):

a) «Жизнь взаймы и без гарантий...».

b) «Жизнь взаймы: нелегко и неприятно ... по инициативе Банка России, которому изрядно надоела практика отвечать деньгами».

24) «Избирательное сродство» (germ.: "Die Wahlverwandschaften", 1809, eng.: "Elective Affinities" (rus.: literal translation «Избирательные сродства душ») a novel by Johann Wolfgang von Goethe (1749-1832), a German writer, philosopher and scientist; translated by A. V. Fyodorov):

a) «Выставка «Избирательное сродство» посвящена поиску человеком своего места в мире».

b) «Идиш и немецкий: Избирательное сродство».

25) «На Западном фронте - без перемен» (eng.: "All Quiet on the Western Front", 1929, a German novel by Erich Maria Remarque; translated by $\mathrm{Yu}$. N. Afonkin):

a) «На Восточном фронте без перемен?»

b) «На фронте евро без перемен?»

Case 4: A translator takes a citation from the other translation, and now - there are two authors of those ever living words:

26) «Вся королевская рать» (eng.: “All the King's Men", an abstract from the "HumptyDumpty Song", translated by Samuil Ya. Marshak (1887-1964)):

«Шалтай-Болтай

Сидел на стене.

Шалтай-Болтай

Свалился во сне.

Вся королевская конница,

Вся королевская рать. 
Не может

Шалтая,

Не может

Болтая,

Шалтая-Болтая,

Болтая-Шалтая,

Шалтая-Болтая собрать!».

The phrase has entered the social and political lexis due to the Russian translation of the title (rus.: «Вся королевская рать»; literally: «Все люди короля») by V. Golyshev in 1969. The novel was written by an American writer Robert Penn Warren (1905-1989), saying about the fate of Willie Stark, a politician and populist. The main character has a prototype: in his novel, Warren referred to Huey Long, a senator, who in 1933 opened a populist campaign under the slogan "Every man is a King".

Case 5: An abstract from the translation is propagated by another author.

27) «О люди! Порождение крокодилов!» ("The Robbers", 1781, a drama by Friedrich Schiller (1759-1805), Act 1, Scene 2). A part of the speech by Charles Moor (rus.: «Люди, люди! Порождение крокодилов! Ваши слезы - вода! Ваши сердияа - твердый булат! Поцелуи - кинжальв в грудь!» translated by Nikolai Khristoforovich Ketcher, a Russian writer and translator, in 1828). In this country the phrase gained prominence after the play staging «Лec» (eng.: "Forest") by A.N. Ostrovsky, in which these words with the whole original pathos exaggerating, are declaimed by a provincial actor Neschastlivtsev in Act 5, Scene 9).

Case 6: A translator manages to formulate the idea quite aphoristically and eloquently. Then, readers mostly associate it with a certain character or author, but never with the translator. However, with a course of time such phrases becomes language unities and start functioning as sayings, and thus, any particular author is not necessary to be mentioned.
Let's look first at a commonly known description of Karlson, who "lives on the Roof":

28) «- Сколько мне лет? - переспросил Карлсон. - Я мужчина в самом расивете сил, больше я тебе ничего не могу сказать.А в каком возрасте бывает расивет сил?В любом! - ответил Карлсон с довольной ульбкой. - В любом, во всяком случае, когда речь идет обо мне. Я красивый, умный и в меру упитанный мужчина в самом расцвете сил». ("Karlson-on-the-Roof" by Astrid Lindgred; translated by Lilianna Lungina).

29) «А король-то - гольий!» (originally “The Emperor's New Clothes", a Danish fairytale by Hans Christian Andersen; translated by Anna and Boris Ganzen).

30) «Mbl в ответе за тех, кого приручили...» (“The Little Prince" by Antoine de Saint-Exupery; translated by Nora Gal).

31) «Каждое утро приводи в порядок свою планету» (“The Little Prince" by Antoine de Saint-Exupery (1900-1944)). The phrase by Little Prince: "It is a question of discipline [...] When you've finished your own toilet in the morning, then it is time to attend to the toilet of your planet [...]" - rus.: «Есть такое твердое правило... Встал поутру, умылся, привел себя в порядок - и сразу приведи в порядок свою планету» (translated by Nora Gal).

32) «Лишь тот достоинжизни и свободы, / Кто каждый день идет за них на бой» (germ.: Nur der verdient sich Freiheit wie das Leben, / Der täglich sie erobern muss!" in "Faust" by Johann Wolfgang von Goethe; translated by N.A. Kholodovsky).

33) «Пепел Клааса стучит в мое сердиее ("The Legend of Thyl Ulenspiegel and Lamme Goedzak", 1867, by Belgian author Charles De Coster (1827-1879); words belong to Thyl Ulenspiegel, the main character; translated by unknown author in 1915). The plot develops 
against the backdrop of the fight between the Beggars and Spanish invaders.

34) «Нет человека, который был бы как Остров, сам по себе, каждый человек есть часть Материка, часть Суши; и если волной снесёт в море береговой Утёс, меньше станет Европа, и так же, если смоет край мыса или разрушит Замок твой или друга твоего; смерть каждого Человека умаляет и меня, ибо я един со всем Человечеством, а потому не спрашивай, по ком звонит колокол: он звонит по Тебе (Джон Донн)» (Epigraph to the novel "For whom the Bell Tolls" by Ernest Hemingway; translated by Ye. Kalashnikova and N. Volzhina; the other less known Russian variant «По ком бьёт набат»).

35) «Боливар не вынесет двоих» (“Roads We Take", 1910, an American story by O. Henry (William Sydney Porter 1862-1910); translated by N. Daruzes). Bolivar is the name of horse who could help two friend to survive, but one of them (Shark Dodson) rated and made himself safe. To explain such behaviour, he says: "Bolivar cannot carry double".

36) «Все равны, но некоторые равнее других» (“Animal Farm”, 1945, a dystopian novella by George Orwell (Eric Arthur Blair, 1903-1950); translated by D. Ivanov, V. Nedoshivin and V. Pribylovsky).

37) «Единственная настоящая роскошьэто роскошь человеческого общения» (“Wind. Sand and Stars", 1939, a memoir by Antoine de Saint-Exupery; translated by Nora Gal).
38) «Люди, будьте бдительнь!!» (Czech.: "Lude, milovaljsem vas. Bdete!"): closing remarks in "Reportage by a Man With a Noose Around His Neck", by a figure in the Czechoslovak communist movement and antiNazi resistance in the World War II, a writer Julius Fucik (1903-1943). He was detained by Nazi and casted into Pankrac Prison in Prague. In this time he wrote his last will book. A. Kolinsky, a warder, brought him papers and pencils in the cell, smuggled out written pieces and kept them at Fucik's friends. The book was finished on $8^{\text {th }}$ September 1943. On the $25^{\text {th }}$ of August in Berlin the writer and patriot J. Fucik was sentenced to death by the Nazi court, and hanged on $8^{\text {th }}$ September 1943. After the end of the War, in May 1945, his wife Gusta Fucikova (who had also been released from Nazi concentration camp) retrieved all of his prison writings in Prague, in 1946. The book was translated into Russian by V. Andryanov in 1947 under the title "A Word Before Execution" (literally: «Слово перед казнью»).

This all brings us to say, that fiction translators through their skills and experience contribute to the literary culture equally as the authors. They enrich their mother tongue, make understanding of the world more colourful and interesting process, involving all people. Thus, translators perform not only as creators for such bridges, but they also create ideas, essences and, consequently, - traditions in the whole Great World Culture. 


\title{
«Земную жизнь пройдя до половины, я очутился...»: \\ Где же очутился художественный переводчик? \\ (переводческий скетч)
}

\author{
И.С. Алексеева \\ Российский государственный педагогический университет \\ им. А.И. Гериена \\ Санкт-Петербургская высшая школа перевода \\ Россия, 191186, Санкт-Петербург, ул. Казанская, 3 а
}

Настоящая статья посвящена вопросу о смене облика и функиий художественного перевода как реакиии на современное восприятие и интерпретирование художественных произведений, принадлежащих мировой культуре. Формат переводческого скетча позволяет автору в свободной форме рассуждать о том, как переводчики становятся создателями мета-языковых маркеров в принимающей культуре, смыслов и традиций - элементов, важных для существования любой культуры. Использованный в статье материал и яркие примеры дают автору возможность вновь напомнить читателям о том, что труд и мастерство переводчиков художественной литературы вносят существенный вклад в прочесс обогащения содержательной стороны русской культуры.

Ключевые слова: художественный перевод, художественное произведение, словесная культура, мосты, метаязык, афоризм, аллюзия.

Научная спечиальность: 10.00.00 - филологические науки. 